\title{
ENDOLYMPHATIC SAC TUMOR AND VON HIPPEL-LINDAU DISEASE IN A SINGLE FAMILY
}

\author{
Patrícia Pires Netto Safatle , Luciano Farage ${ }^{2}$, André Sampaio ${ }^{3}$, Frederico Abreu Soares Ferreira ${ }^{4}$, \\ Heloisa Pires Netto Safatle ${ }^{5}$, Carlos Augusto Oliveira ${ }^{6}$, Iris Ferrari ${ }^{7}$
}

Endolymphatic sac tumors are low-grade adenocarcinoma of temporal bone, locally invasive ${ }^{1-3}$. Their origin was controversial but showed to originate from endolymphatic sac and duct epithelium ${ }^{2,4,5}$. They are uncommon tumors and occur sporadically, or more frequently, associated with von Hippel-Lindau $(\mathrm{VHL})^{3,6-8}$ disease. The most common clinical presentations are: progressive deafness, tinnitus and vertigo. The hearing loss is typically irreversible, acute, progressive or gradual ${ }^{6,9}$. We illustrate a familial appearence of endolymphatic sac tumor. During the evaluation of other family members the diagnosis of von Hippel-Lindau disease came up. VHL is a genetic affection, autosomic dominant, with almost complete penetration (95\%). The syndrome includes renal cysts and renal carcinoma, pancreatic cysts, neuroendocrine tumors, pheochromocytoma, cystadenomas of the reproductive adnexal organs, and hemangioblastomas of the nervous central system and retina ${ }^{8,10}$.

We describe two cases of endolymphatic sac tumors in two siblings from different fathers and with a VHL affected mother.

\section{CASES}

Case 1

A male patient presented hearing reduction in the left ear since he was 17 years old. At that time, he was evaluated by computed tomography (CT) of the ear that showed temporal bone erosion. He was submitted to surgical resection with histological confirmation of adenocarcinoma of endolymphatic sac. He was treated at an outside institution and we don't have any further information.

Case 2

A female patient 15 years old, five years after the diagnosis

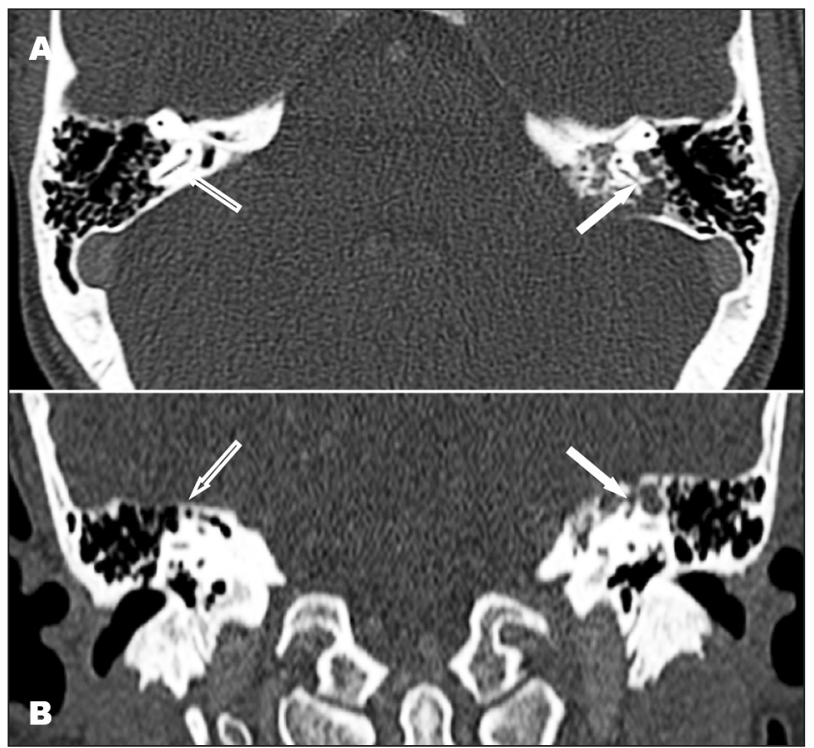

Fig 1. [A] Axial and [B] coronal CT show temporal bone erosion involving the endolymphatic sac and posterior semicircular canal at left side (solid arrow), compare with the normal contralateral structures (open arrow).

of her brother (Case 1) presented a progressive left side hearing loss associated with vertigo during the last 6 months. Audiometric evaluation showed a severe sensorineural hearing loss (high frequency). Temporal bone destruction envolving the endolymphatic sac and posterior semicircular canal was seen at CT at left side (solid arrow), compared to the normal contralateral structures (open arrow) (Fig 1A and B). At magnetic resonance imaging (MRI) a minimally enhanced mass between the sigmoid sinus and the internal auditory canal, measuring $2.5 \mathrm{~cm}$ (Fig 2A and B) and destroying the posterior semicircular canal was found (Fig 2C).

She underwent surgical resection by a retrolabyrinthinetransdural approach. Using an extended postauricular incision,

\section{TUMOR DO SACO ENDOLINFÁTICO E DOENÇA DE VON HIPPEL-LINDAU ENVOLVENDO UMA FAMÍLIA}

Serviços de Radiologia, Otorrinolaringologia e Genética Clínica do Hospital Universitário de Brasília, Universidade de Brasília (UnB), Brasília DF, Brazil: ${ }^{1}$ Médica Residente de Radiologia e Diagnóstico por Imagem, Hospital Universitário de Brasília (HUB), Universidade de Brasília (UnB); ${ }^{2}$ Médico Neurorradiologista, Doutorando do Programa de Pós-graduação em Ciências Médicas da Faculdade de Medicina (FM) da UnB; ${ }^{3}$ Doutor em Ciências da Saúde e Médico Otorrinolaringologista do Setor de Implante Coclear do HUB/UnB; ${ }^{4}$ Médico Radiologista, Hospital Regional do Paranoá, Secretaria de Estado da Saúde do Distrito Federal; ${ }^{5}$ Doutora em Genética e Médica Geneticista do Serviço de Genética Clínica do HUB/UnB; ${ }^{6}$ Professor Titular de Otorrinolaringologia da FM/UnB e Chefe do Serviço de Otorrinolaringologia do HUB/UnB; ${ }^{7}$ Professora Titular de Genética Clínica, Departamento de Genética e Morfologia, Instituto de Biologia, UnB e Chefe do Serviço de Genética Clínica do HUB/UnB.

Received 1 March 2009, received in final form 3 August 2009. Accepted 11 September 2009.

Dr. Luciano Farage - SQS 207 Bloco A / 201 - 70253-010 Brasilia DF - Brasil. E-mail: lucianofarage@yahoo.com.br 


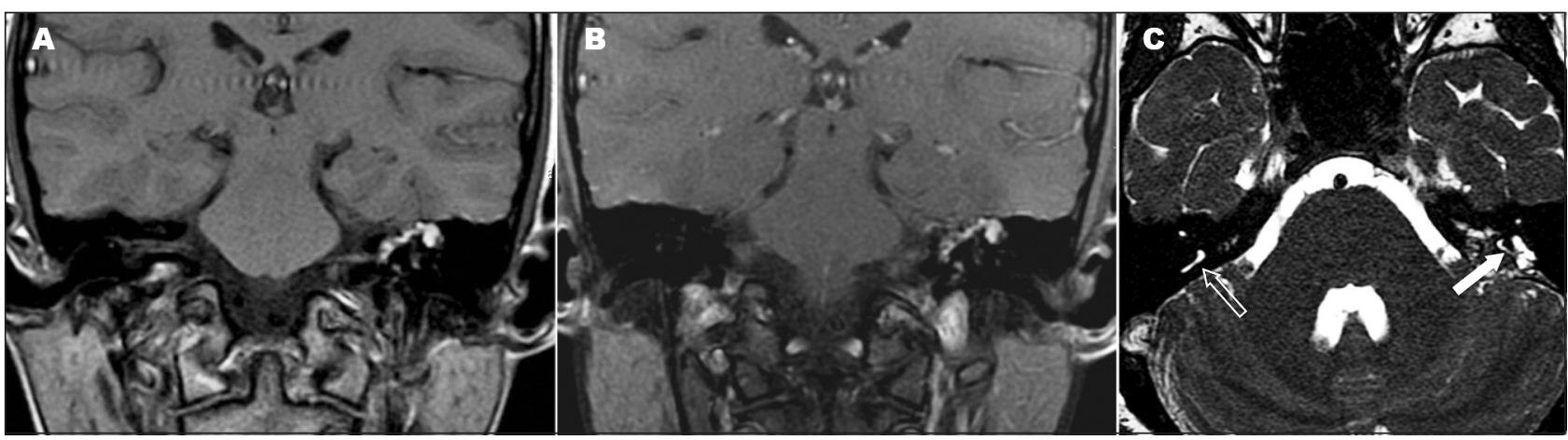

Fig 2. $[A]$ Coronal TI, [B] coronal T1 post contrast and with fat saturation show hyperintense nodular mass with bone destruction with little enhancement after gadolinium. No vessel involvement was seen. The hyperintense signal at T7WI may be explained by hemoglobin product degradation-extracellular methemoglobin. [C] Axial 3D-CISS show the mass involving the posterior semicircular canal (white arrow), compare with the normal contra lateral (open arrow).

a mastoidectomy was performed with identification of the horizontal semicircular canal and facial nerve. The jugular bulb was skeletonized, as was the tegmental dura and the sinodural angle. After identifying and skeletonizing the posterior semicircular canal wich was totally invaded, the outline of a bulging tumor-filled endolymphatic sac was seen. The posterior semicircular canal was sealed quickly with bone wax. A margin of at least $0.5 \mathrm{~cm}$ around the sac on healthy posterior fossa dura was obtained as the sac and duct were removed enbloc. This procedure was performed after removing tumor-laden bone from the posterior dural surface using the high-speed drill. The antrum was then sealed with bone wax; abdominal fat was used to seal the dura with the aid of a tissue sealant to prevent cerebrospinal fluid leaks. A histological confirmation of endolymphatic sac tumor was obtained.

She was discharged home 2 days after surgery with rotational vertigo solved in a few days. The patient has been well since the post operative time but her hearing got worse.

She also had an abdominal ultrasound (US) evaluation unremarkable.

\section{Case 3}

Female patient, mother of the two previous cases, assintomatic until 48 years old. She was evaluated because of the confirmation of the endolymphatic sac tumor of her children. She was submitted to a screening protocol of von Hippel-Lindau ${ }^{10-}$ ${ }^{12}$ including abdominal US, CT and MRI, head and spine MRI and temporal bone CT. The diagnosis was based on a clinical-radiological study that showed pancreatic cysts and small round cystic lesions with wall enhancement in the cerebellum, problably hemangioblastomas, and a mass in left kidney that could possibly be clear cell carcinoma. She was also seen by a genetic counseler.

All patients or their legal representatives signed an informed consent in orther to have their data reported.

\section{DISCUSSION}

The von Hippel-Lindau (OMIM 193300) is an autosomic dominant disorder related to an anomalous tumor suppressor gene located at short arm of chromosome 3 $(3 \mathrm{p} 25-\mathrm{p} 26)^{8,10}$. The prevalence is estimated at around 1 in every 39000 people $e^{8,10,11}$. Affected patients have an increased risk of developing benign or malignant highly vascularized tumors in multiple systems, including central nervous system, kidneys, pancreas, adrenals, epididymis and adnexia ${ }^{8,10,11}$. In those cases, the second copy of the VHL gene is also deleted or inactivated, this finding suggests that the VHL plays role as a recessive tumor suppresor gene ${ }^{12-14}$.

Recently, primary low-grade endolymphatic sac adenocarcinoma was noted as another neurotologic neoplastic manifestation of the disease $\mathrm{s}^{3,6,8}$ afecting $15 \%$ of $\mathrm{VHL}$ patients ${ }^{4,10}$. It may occur sporadically, but it is uncomon. When it appears bilateraly it is allways related to $\mathrm{VHL}$ disease $e^{4-10}$.

Heffner ${ }^{2}$ has described the tumor and related it to its origin in the sac and duct endolymphatic. He published one of the largest series until now with 20 cases. Gasker et al. ${ }^{15}$ evaluated the effect of $\mathrm{VHL}$ mutation on the duct and endolymphatic sac and some $\mathrm{VHL}$ patients present celular changes without detectable tumor that may be related to preneoplasic events.

The most common symptoms include: auditive impairment, vertigo and tinnitus ${ }^{4,7}$. Hearing loss may be sudden but is usually slowly progressive, especially in patients who do not have $\mathrm{VHL}$ and often may have been misdiagnosed earlier with Meniere's disease. Hearing loss in patients who have VHL occurs early in life and is not reversible like happend in our the index case (Case 2). Because of the irreversible hearing loss associated with the tumor, early surgical intervention is important to prevent permanent neurological symptoms and deficits. Total ressection is curative and no other adjunt therapy is necessary ${ }^{8,16}$.

The underlying mechanisms of audio vestibular impairment are not fully understood. It may be related to tumor infiltration of the internal ear, hemorrhage or hidrop- 
sy of endolymphatic $\mathrm{sac}^{4,7}$. Most of the patients have Meniere's-like symptoms years before the diagnosis of endolymphatic sac tumor which raised the possibility that early manifestations of tumor growth included perturbations of vestibular aqueduct function and the development of endolymphatic hydrops-related symptomatology ${ }^{4}$.

As tumors enlarge, the patient may experience tumor presentation in the external auditory canal, which appears as a polypoid mass. Usually by this time, facial paralysis and deafness have become apparent and the patient experiences symptoms of cerebellopontine angle extension, including headache secondary to brainstem compression ${ }^{4,16}$.

The auditory impairment is irreversible, occuring in young people, ages ranging around their twenties ${ }^{7}$. Because of the irreversible hearing loss associated with the tumor, early surgical intervention is important to prevent permanent deafness. Total ressection is curative and no other adjunt therapy is necessary ${ }^{8,16}$.

MRI has been used to evaluated this tumor and the most common finding is a destructive mass between internal auditory canal and sigmoid sinus. The imaging presents a variable signal at $\mathrm{T} 1$ and $\mathrm{T} 2$ weighted images (WI), usually a high $\mathrm{T} 1$ signal is present and is related to hemoragic contents. Contrast enhancement is also variable from minimum to significant. No histologic changes has been related to this signal variation. Our patient (Case 2) had minimum enhancement and high $\mathrm{TI} \mathrm{WI}$ problably related to blood products. CT evaluation is always necessary because of its suberb capability in bone evaluation and play an adjunct role on inner and middle ear evaluation ${ }^{2,4,9,16-20}$.

VHL disease spectrum includes retinal, cerebellum, medulla and spinal cord hemangioblastoma, pancreatic and kidney cysts, clear cell kidney carcinoma, pheocromocitoma, neuroendocrine tumors, cystadenoma/cystadenocarcinoma of reproductive organs and endolymphatic sac tumors ${ }^{10,11}$. The disease has a variable expression and a penetrance of $95 \%^{11}$; a few patients show all manifestations and half of all have just one of the above tumors. Retinal hemangioblastomas generally occur first around the age of 25 , otherwise cerebellar hemangiomas happen around the age of 30 and kidney cancer around the age of $37^{3,8,10,11}$.

VHL diagnosis is clinically based on the following criteria: two or more hemangioblastoma at CNS; one CNS hemangioblastoma associated to a visceral manifestation; and any manifestation when a positive family history is present ${ }^{3,8,10,11}$. The molecular evaluation confirms a clinical diagnosis and is feasible to make an asymptomatic relative diagnosis.

After diagnostic confirmation the affected people must undergo periodical screening tests ${ }^{12}$ that includes annual urinary catecolamines, oftalmoscopy and abdominal US or CT and every two years a brain and spine MRI. In case of simptoms the patients must be immediately and properly evaluated. A proper screening allows an early di- agnosis of VHL manifestations, that may reduce morbidity and mortality. The major causes of death in those patients include complications of hemangioblastomas and renal carcinoma metastases".

Radiologists play a central role in the diagnosis and orientation of those patients, because they recognize lesions and their associations, and can suggest the diagnosis to reduce the morbidity by making early diagnosis ${ }^{7,11,15}$.

The recognition of endolymphatic sac tumor as manifestation of von Hippel-Lindau disease, rather than a sporadic tumor leads to the investigation of other systems and clarify the role of the imaging techniques for the work out of these patients.

\section{REFERENCES}

1. Hassard AD, Boudreau SF, Cron CC. Adenoma of the endolymphatic sac. J Otolaryngol 1984;13:213-216.

2. Heffner DK. Low-grade adenocarcinoma of probable endolymphatic sac origin: a clinicopathologic study of 20 cases. Cancer 1989;1;64:2292-2302.

3. Manski TJ, Heffner DK, Glenn GM, et al. Endolymphatic sac tumors: a source of morbid hearing loss in von Hippel-Lindau disease. JAMA 1997;14;277:1461-1466.

4. Butman JA, Kim HJ, Baggenstos M, et al. Mechanisms of morbid hearing loss associated with tumors of the endolymphatic sac in von Hippel-Lindau disease. JAMA 2007;1:298:41-48.

5. Heffner DK. Are papillary adenomas endolymphatic sac tumors? Ann Otol Rhinol Laryngol 1996;105:251-252.

6. Choo D, Shotland L, Mastroianni M, et al. Endolymphatic sac tumors in von Hippel-Lindau disease. J Neurosurg 2004;100:480-487.

7. Lonser RR, Baggenstos M, Kim HJ, Butman JA, Vortmeyer AO. The vestibular aqueduct: site of origin of endolymphatic sac tumors. J Neurosurg 2008;108:751-756

8. Lonser RR, Kim HJ, Butman JA, Vortmeyer AO, Choo DI, Oldfield EH. Tumors of the endolymphatic sac in von Hippel-Lindau disease. N Engl J Med 2004;350:2481-2486

9. Jensen RL, Gillespie D, House P, Layfield L, Shelton C. Endolymphatic sac tumors in patients with and without von Hippel-Lindau disease: the role of genetic mutation, von Hippel-Lindau protein, and hypoxia inducible factor-1alpha expression. J Neurosurg 2004;100:488-497.

10. Butman JA, Linehan WM, Lonser RR. Neurologic manifestations of von Hippel-Lindau disease. JAMA 2008;300:1334-1342.

11. Choyke PL, Glenn GM, Walther MM, Patronas NJ, Linehan WM, Zbar B. von Hippel-Lindau disease: genetic, clinical, and imaging features. Radiology 1995;194:629-642.

12. Hes FJ, Feldberg MA. Von Hippel-Lindau disease: strategies in early detection (renal-, adrenal-, pancreatic masses). Eur Radiol 1999;9:598-610.

13. Knudson AG, Jr. Hereditary cancer, oncogenes, and antioncogenes. Cancer Res 1985;45:1437-1443.

14. Knudson AG, Jr. Genetics of human cancer. J Cell Physiol 1986;4 (Suppl): S7-S11.

15. Glasker S, Lonser RR, Tran MG, et al. Effects of VHL deficiency on endolymphatic duct and sac. Cancer Res 2005;65:10847-10853.

16. Roche PH, Dufour H, Figarella-Branger D, Pellet W. Endolymphatic sac tumors: report of three cases. Neurosurgery 1998;42:927-932.

17. Ho VT, Rao VM, Doan HT, Mikaelian DO. Low-grade adenocarcinoma of probable endolymphatic sac origin: CT and MR appearance. AJNR Am J Neuroradiol 1996;17:168-170.

18. Kilickesmez O. Endolymphatic sac tumor in a patient with von HippelLindau disease: MR imaging findings. Diagn Interv Radiol 2006;12:14-16.

19. Lo WW, Applegate LJ, Carberry JN, et al. Endolymphatic sac tumors: radiologic appearance. Radiology 1993;189:199-204.

20. Mukherji SK, Albernaz VS, Lo WW, et al. Papillary endolymphatic sac tumors: CT, MR imaging, and angiographic findings in 20 patients. Radiology 1997;202:801-808. 